\title{
Effect of moisture on dental enamel in the interaction of two orthodontic bonding systems
}

\author{
André Pinheiro de Magalhães Bertoz¹, Derly Tescaro Narcizo de Oliveira², Carla Maria Melleiro Gimenez³, \\ André Luiz Fraga Briso ${ }^{4}$, Francisco Antonio Bertoz ${ }^{5}$, Eduardo César Almada Santos ${ }^{4}$
}

Objective: The purpose of this study was to assess by means of scanning electron microscopy (SEM) the remaining adhesive interface after debonding orthodontic attachments bonded to bovine teeth with the use of hydrophilic and hydrophobic primers under different dental substrate moisture conditions. Material and Methods: Twenty mandibular incisors were divided into four groups $(\mathrm{n}=5)$. In Group I, bracket bonding was performed with Transbond MIP hydrophilic primer and Transbond XT adhesive paste applied to moist substrate, and in Group II a bonding system comprising Transbond XT hydrophobic primer and adhesive paste was applied to moist substrate. Brackets were bonded to the specimens in Groups III and IV using the same adhesive systems, but on dry dental enamel. The images were qualitatively assessed by SEM. Results: The absence of moisture in etched enamel enabled better interaction between bonding materials and the adamantine structure. The hydrophobic primer achieved the worst micromechanical interlocking results when applied to a moist dental structure, whereas the hydrophilic system proved versatile, yielding acceptable results in moist conditions and excellent interaction in the absence of contamination. Conclusion: The authors assert that the best condition for the application of primers to dental enamel occurs in the absence of moisture.

Keywords: Dental primer. Scanning electron microscopy. Orthodontic brackets.

Objetivo: a proposta desse estudo foi avaliar, por meio de microscopia eletrônica de varredura (MEV), a interface adesiva após a descolagem de acessórios ortodônticos, fixados em dentes bovinos com emprego de adesivo hidrofílico e hidrofóbico, em condições distintas de umidade do substrato dentário. Métodos: foram utilizados 20 incisivos inferiores, divididos em quatro grupos $(n=5)$ : Grupo I , empregou-se o sistema de colagem contendo o primer hidrofilico Transbond MIP e a pasta adesiva Transbond XT, aplicados em substrato úmido; Grupo II, empregou-se o sistema de colagem primer hidrofóbico Transbond XT e pasta adesiva em substrato úmido; Grupos III e IV, os braquetes foram colados com os mesmos sistemas de união dos Grupos I e II, porém com esmalte dentário seco. Removidos os acessórios, avaliou-se em MEV, em diferentes magnificações, a interface adesiva e a interação dos sistemas adesivos com o esmalte dentário. As imagens foram avaliadas qualitativamente, observando-se o embricamento mecânico para o adesivo hidrófilo em quaisquer condições de substrato. Resultados: a falta de umidade no esmalte condicionado permitiu uma melhor interação entre os materiais de ligação e a estrutura adamantina. $\mathrm{O}$ adesivo hidrofóbico apresentou o pior resultado de interação micromecânica quando aplicado a uma estrutura dentária úmida; já o sistema hidrofilico mostrou-se versátil, obtendo resultados aceitáveis em condições de umidade e excelente interação na ausência de contaminação. Conclusão: os autores afirmam que a melhor condição do esmalte dentário para a aplicação de primers é com a ausência de umidade.

Palavras-chave: Adesivos dentinários. Microscopia eletrônica de varredura. Braquetes ortodônticos.

${ }^{1}$ Substitute professor of Orthodontics, College of Dentistry —Araçatuba/State University of São Paulo (UNESP).

${ }^{2}$ Doctorate student in Orthodontics, College of Medicine — São José do Rio Preto (FAMERP).

${ }^{3} \mathrm{PhD}$ in Orthodontics, College of Dentistry - Araçatuba/UNESP.

${ }^{4}$ Adjunct professor of Cosmetic Dentistry, College of Dentistry - Araçatuba/ UNESP.

${ }^{5}$ Full professor of Orthodontics, College of Dentistry —Araçatuba/UNESP.

Submitted: February 14, 2011 - Revised and accepted: September 18, 2011
How to cite this article: Bertoz APM, Oliveira DTN, Gimenez CMM, Briso ALF, Bertoz FA, Santos ECA. Effect of moisture on dental enamel in the interaction of two orthodontic bonding systems. Dental Press J Orthod. 2013 JulyAug;18(4):89-97.

" The authors report no commercial, proprietary or financial interest in the products or companies described in this article.

Contact address: André Pinheiro de Magalhães Bertoz Faculdade de Odontologia, Departamento de Ortodontia Rua José Bonifácio, 1193 - Araçatuba/SP — Brazil CEP: 16015-050 - E-mail: drbertoz@hotmail.com 


\section{INTRODUCTION}

Bonding procedures are based on histomorphological changes occurring in the enamel due to the action of surface treatments initially proposed by Buonocore in $1955,{ }^{5}$ who noted that the action of acid substances on the adamantine structure enables a micromechanical interaction between resinous materials and etched/conditioned dental enamel.

Subsequently, findings disclosed by Buonocore were used in Orthodontics (1970), producing undeniable clinical benefits. ${ }^{2,5}$ This bonding mechanism remains in use to this day despite numerous changes undergone by orthodontic attachments as well as adhesive systems.

Such benefits led to some unfavorable clinical situations, namely: increased likelihood of injuries to dental enamel structures occurring after bracket removal, since this procedure may damage the enamel surface due to great bond strength. ${ }^{1-5}$ Furthermore, resin remnants remain bonded to the enamel and may not only induce plaque accumulation, but also undermine esthetics. . $^{2,5}$

Therefore, when choosing a bonding system one should consider the type, concentration and etching/ conditioning time, selecting the less deleterious systems, ${ }^{4,5}$ thereby preserving clinical performance.

New bonding systems which blend into one single product both etching and primer materials, have been proposed. With the development of one-step self-etching systems, ${ }^{1-5}$ an estimated reduction of $65 \%$ in the time required for bonding orthodontic brackets was achieved, ${ }^{1,2}$ thus, decreasing the risk of surgical field contamination by oral fluids. Nevertheless, the effects of these bonding agents on tooth enamel have been questioned by lab and clinical studies. ${ }^{8-11}$

New hydrophilic bonding systems have been launched into the dental market. These products address substrate contamination without interfering in the orthodontic bonding process. $6,18,23,25,28$

The foregoing considerations emphasize the importance of shedding light on the true nature of the interaction between hydrophilic primers and dental enamel, and comparing it with the performance of a conventional bonding system under various substrate conditions.

\section{Objective}

This research aims at assessing - by means of scanning electron microscopy (SEM) - the remain- ing adhesive interface after debonding orthodontic attachments bonded to bovine teeth with the use of hydrophilic and hydrophobic primers under different dental substrate moisture conditions: a) Moisture interference in the systems used in this study; b) Advantages of the micromechanical interlocking system under different conditions; c) Systems that provide the best results.

\section{MATERIAL AND METHODS}

The sample for this in vitro study consisted of 20 permanent bovine incisors ${ }^{18}$ freshly extracted from three-year old heifers or steers confined in slaughterhouses. After cleaning the teeth, they were stored in aqueous $0.1 \%$ thymol until use. ${ }^{5-12,17,26}$

Cracks were detected in the enamel by transilluminating the buccal surface of the teeth ${ }^{12}$ with the aid of a stereomicroscope with $1.2 \mathrm{x}$ magnification. Only those teeth which were free from cracks and carious lesions on all surfaces, were selected.

In order to render the buccal surfaces more regular, flat and smooth, they were polished for $10 \mathrm{sec}-$ onds with a rotary polisher (Buehler Ecomet 3) using silicon carbide discs (Buehler) at $150 \mathrm{rpm}$ in decreasing grain size order $(320,600,800,1200)$.

Afterwards, the crowns were polished with felt discs (Buehler) Texmet 1000 soaked in $1 \mu \mathrm{m}$ diamond suspension, followed by $0.3 \mu \mathrm{m}$ suspension (Fig 1).

Subsequently, teeth were randomly divided into four groups according to bonding system and substrate condition (Table I). Pre-adjusted stainless steel maxillary central incisor brackets (Abzil.Lancer) with mesh bases (two-point welding) were bonded to all specimens.

Group I: Specimens had Transbond MIP adhesive system applied according to the manufacturer's recommendations, followed by prophylaxis of the enamel buccal surface carried out by means of pumice, water and a Robinson brush at low speed. In the following step, the enamel surface was etched with phosphoric acid at $37 \%$ for 15 seconds. The entire substrate was then washed with distilled water and excess was removed with absorbent paper, always preserving tissue moisture. Primer was then applied using the brush that comes with the product, followed by gentle jets of compressed air for about 5 seconds. 

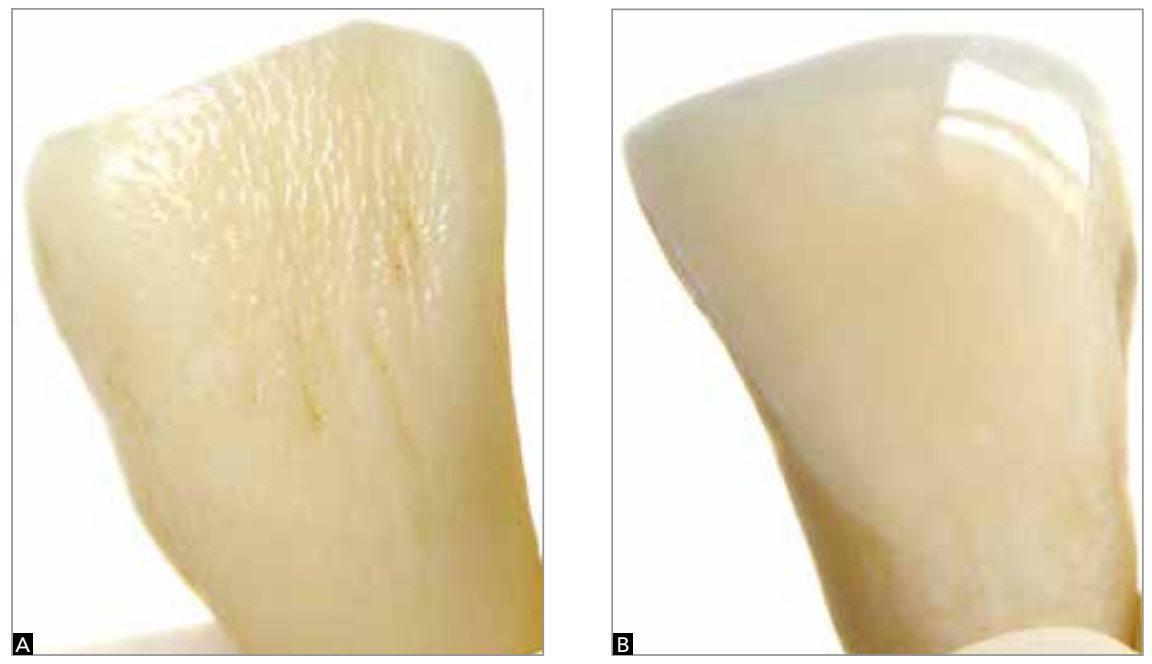

Figure 1 - Bovine teeth before (A) and after (B) polishing the buccal crown surfaces.

Table 1 - Experimental groups, orthodontic bonding material and substrate condition

\begin{tabular}{|c|c|c|c|c|c|}
\hline Group & $n$ & Bonding material & Manufacturer & Batch & Substrate \\
\hline । & 5 & $\begin{array}{l}\text { Transbond MIP } \\
\text { (Moisture Insensitive Primer) }\end{array}$ & 3M/Unitek Dental Products & $\begin{array}{c}6 \mathrm{KN} \\
2008-10\end{array}$ & Moist \\
\hline$\|$ & 5 & Transbond XT & 3M/Unitek Dental Products & $\begin{array}{l}\text { 6CW/6WB } \\
\text { 2007-09 }\end{array}$ & Moist \\
\hline II & 5 & $\begin{array}{c}\text { Transbond MIP } \\
\text { (Moisture Insensitive Primer) }\end{array}$ & 3M/Unitek Dental Products & $\begin{array}{c}6 K N \\
2008-10\end{array}$ & Dry \\
\hline IV & 5 & Transbond XT & 3M/Unitek Dental Products & $\begin{array}{l}\text { 6CW/6WB } \\
\text { 2007-09 }\end{array}$ & Dry \\
\hline
\end{tabular}

Transbond XT light cure adhesive was subsequently applied to the bracket bases under a pressure of $300 \mathrm{~g}$, measured with a tension gauge (Dontrix, ETM Corporation, Monrovia, CA), ${ }^{18}$ to determine the minimum compression weight and ensure similar paste flow on all teeth. Excess was removed with the aid of an explorer \#5 (Duflex SSWhite) accurately circumscribing the Orthodontic Bonding Area (OBA).

Soon afterwards, the materials were light cured for 10 seconds on the mesial and 10 seconds on the distal surface by means of an Ultralux (Dabi Atlante, Ribeirão Preto, Brazil) curing light of $500 \mathrm{~mW} / \mathrm{cm}^{2}$ intensity. The specimens were then immediately debracketed with debonding pliers/AEZ (Ormco Corp. Glendora, CA, USA). The pliers tips were positioned at the bracket/adhesive interface and brackets were pulled off (Fig 2).

Group II: A conventional bonding system was applied to the specimens in this group (Table 1), which underwent the following steps: prophylaxis, etching, substrate moistening, excess removal and light curing, performed in the same manner as described for
Group I, except that for the latter group bonding was performed with Transbond XT adhesive system associated with acrylic resin cement. The specimens were then immediately debracketed using the technique previously described.

Group III: Brackets were bonded to these specimens by means of the Transbond MIP bonding system. The same steps described for Group I were performed, but after etching, washing and drying the tooth surface, the enamel remained completely dry.

Group IV: Brackets were bonded using the conventional bonding system (Transbond XT - 3M Unitek Dental Products) following the same procedures performed for Group II, but under the same substrate conditions adopted for Group III.

All brackets were bonded by a single operator to minimize random errors.

\section{Preparing the specimens for electron micrograph}

In order to assess the adhesive interface, two teeth from each group were cut with a diamond disc 

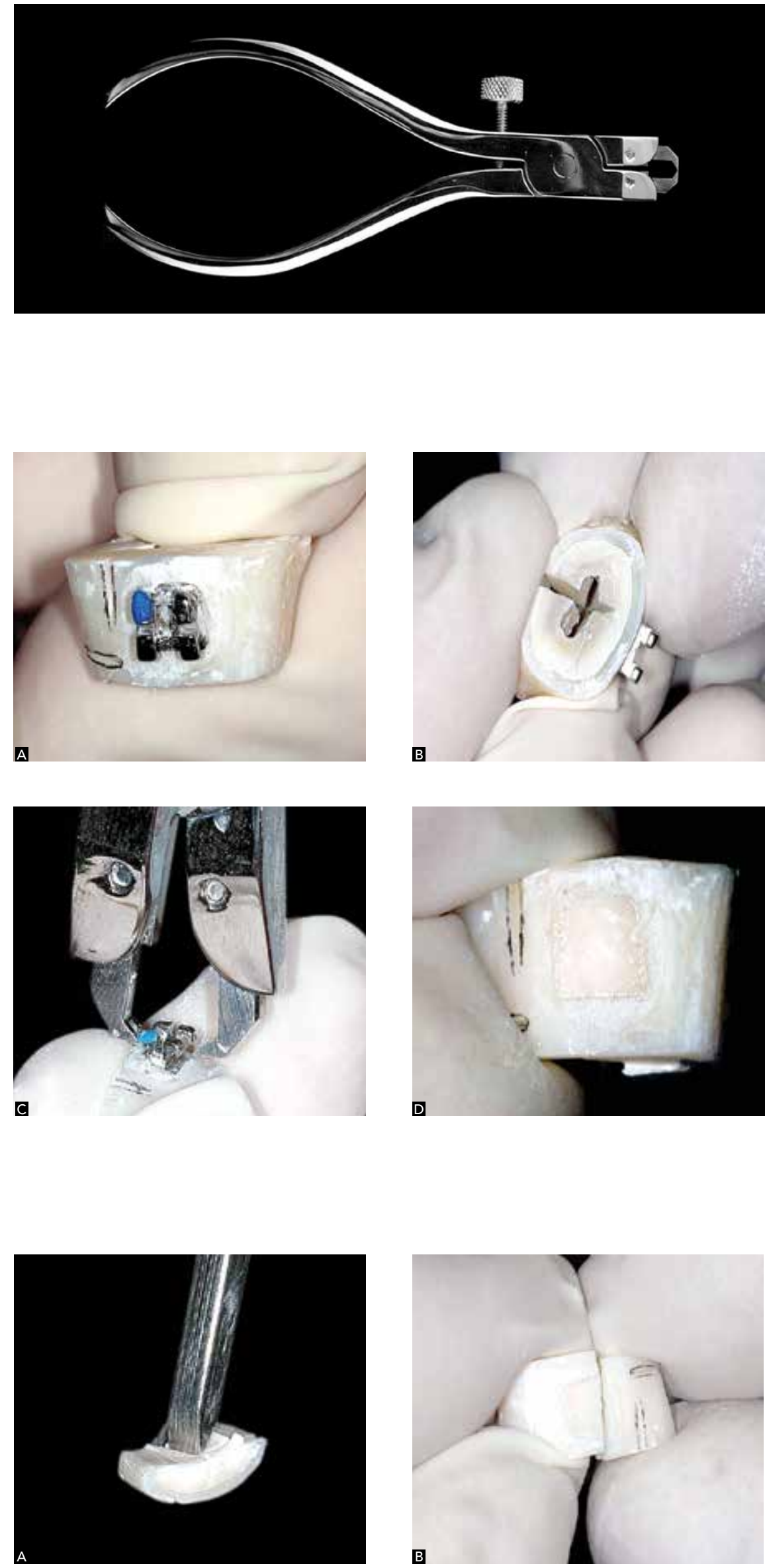

Figure 2 - Debonding plier.

Figure 3 - A) Specimen cut in the orthodontic bonding area. B) Sectioning nearly as far as the buccal enamel. C) Debracketing using debonding pliers/AEZ, D) Specimen after debonding.
Figure 4 - A) Chisel in position to perform fracture. B) Specimen transversely fractured for SEM assessment 
(Buehler, Lake Bluff, IL, USA), yielding small dental fragments where the brackets had been previously bonded (Fig 3).

The area was subsequently fractured with a gouge chisel tip (Duflex SSWhite) to enable microscopic analysis of the adhesive interface (Fig 4). To highlight such an interface, etching was carried out with phosphoric acid for 5 seconds and rinsed with water for 20 seconds.

The fragments obtained from each specimen were placed on stubs, identified and metallized with gold alloy to render the surface electrically conductive (Fig 5).

\section{Microscopic analysis of the adhesive interface}

The SEM device (JEOL JSM5600 LV, Japan) was set at $13 \mathrm{KV}$ voltage acceleration at a working distance of 30 $\mathrm{mm}$. Images were obtained at 1300, 3000, 6000-times magnification. The adhesive interface underwent qualitative analysis and the photographed regions were representative of each specimen.

\section{RESULTS}

The most representative regions of each specimen were evaluated, taking into account the adhesive interface (assessment at $1400 \mathrm{X}$ ) and the quality of the micromechanical interlocking (assessment at $1300 \mathrm{X}$, $3000 \mathrm{X}$ and $6000 \mathrm{X}$ magnification).

In Group I, the adhesive interface showed good micromechanical interlocking, developing tags $(\mathrm{T})$ and few gaps (L), indicative of decalcified regions not fully filled with adhesive material, possibly due to the presence of water. In general, these characteristics indicate that Transbond MIP hydrophilic adhesive system had a satisfactory interaction with the enamel, even in the presence of moisture (Fig 6A).

This interaction was better assessed after removing the mineral content, assessing the micromechanical interlocking and the surface topography of adhesive remnants at $1300 \mathrm{X}, 3000 \mathrm{X}$ and $6000 \mathrm{X}$ magnification (Figs 6B, 6C and 6D).

Figure $6 \mathrm{~B}$ reveals that there was homogeneous penetration of the adhesive system across the study area (Ad), showing that the presence of moisture did not prevent the adhesive from penetrating the etched area. Here, the presence of Gaps $(\mathrm{L})$ in etched areas are more evident, which enables increased penetration of the adhesive material.

At higher magnifications (Figs 6C and 6D), it appears that there was in-depth micromechanical inter-

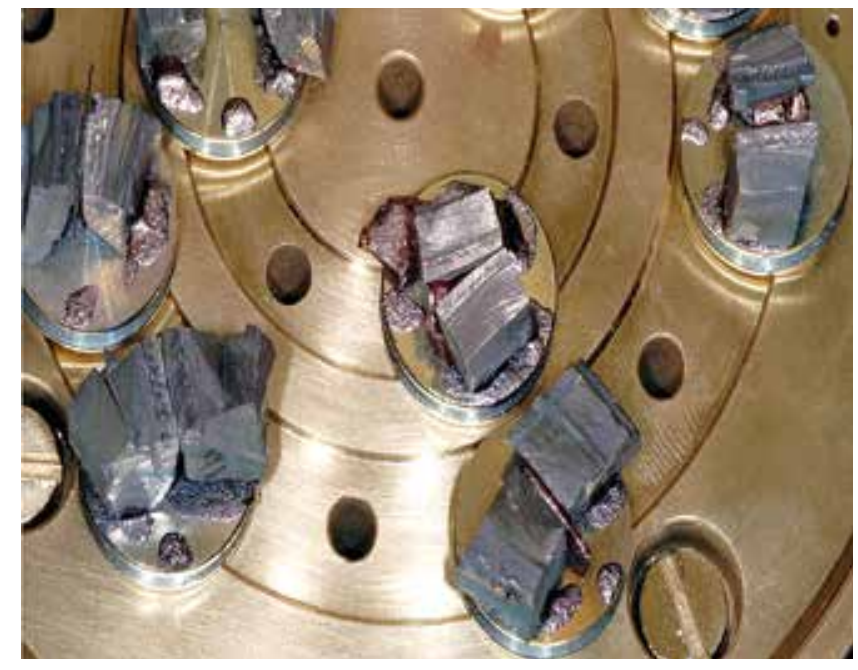

Figure 5 - Metallized specimens placed on stubs

action in the enamel structure, preserving much of the mineralized prismatic area (Ep), although in some places there was partial dissolution of the rods generating nano interlocking areas with inter-crystallite adhesive penetration (Pic).

Group II showed (Fig 7A) the presence of clear, extensive and wide gaps (L) all over the bonding interface. These observations confirm that the presence of moisture, to some extent, insulated the substrate and did not allow satisfactory micromechanical interlocking to take place, since irregular and scarce tags $(\mathrm{T})$ became visible in restricted and isolated areas.

With the removal of the mineral content (Figs 7B, 7C and 7D), the bonding system (Sc) showed irregular topography and the presence of gaps (L). This means that water filled most of the area that had been demineralized by the phosphoric acid, which not only prevented the inter prismatic spaces from being filled up, but also hindered inter crystallite penetration by the adhesive system.

As for Groups III and IV, (teeth treated with Transbond MIP hydrophilic primer and hydrophobic Transbond XT Primer (Sc), respectively) the enamel/adhesive interface (Figs 8A and 9A) showed good micromechanical interaction with the enamel $(E)$, absence of cracks and the development of numerous and continuous tags $(\mathrm{T})$. These characteristics demonstrate that the application of phosphoric acid followed by rinsing and drying of the surgical field, produces excellent adhesive interfaces regardless of the primer used for bonding.

At larger amplitudes and after removal of the mineral content (Figs 8B and 9B), it became apparent that 

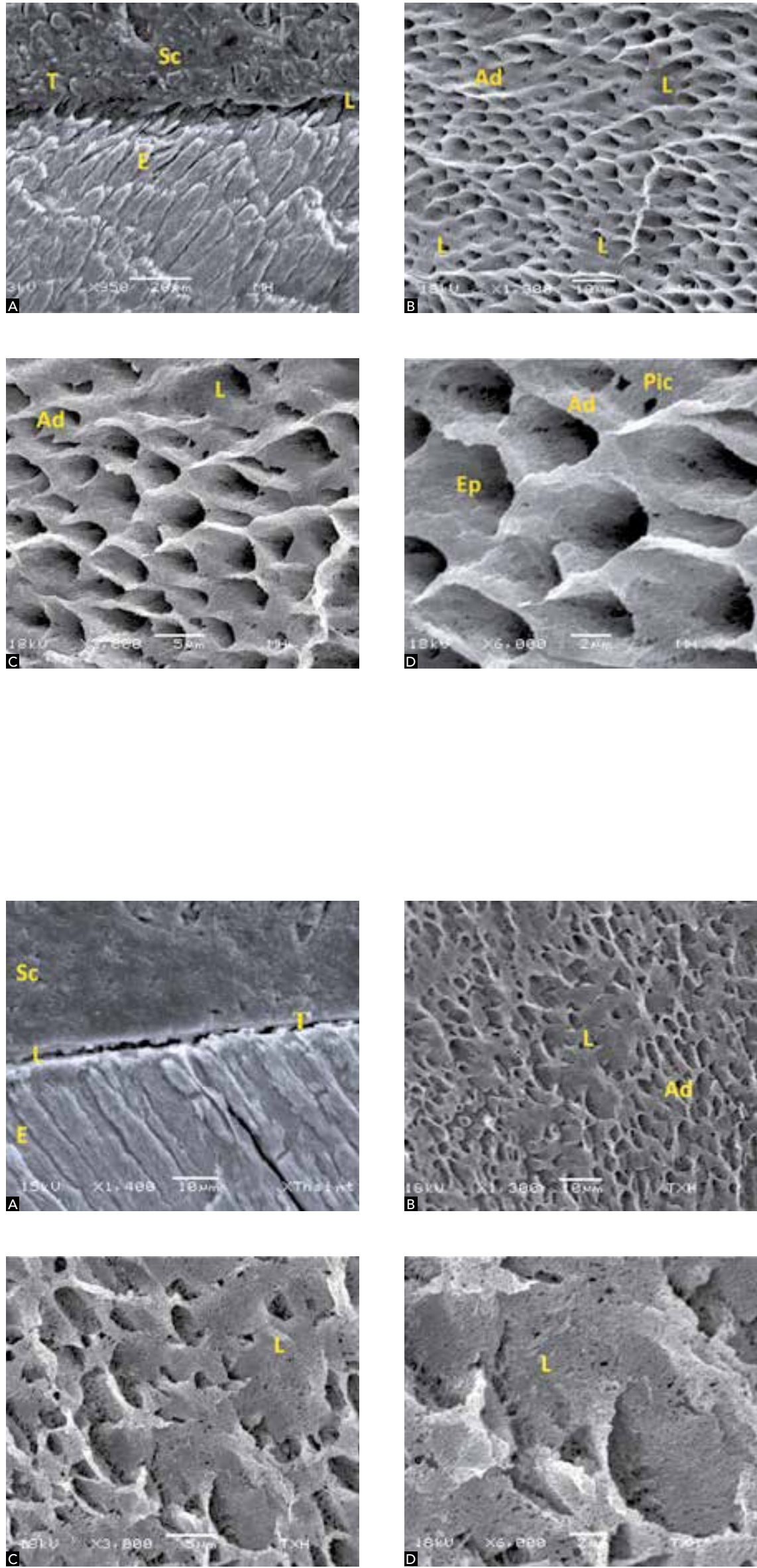
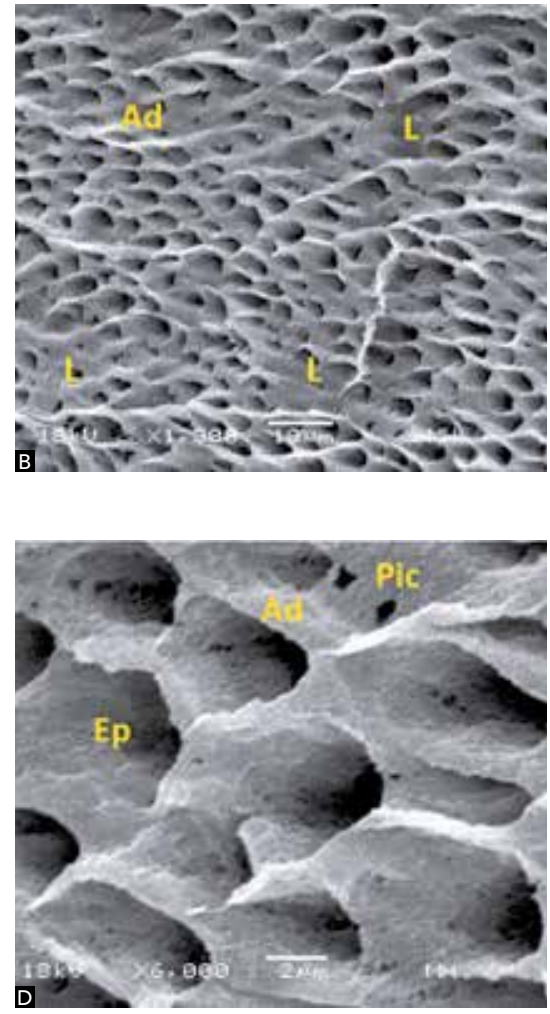

Figure 6 - Electron micrographs: Moist MIP and enamel bonding interface. A) Relationship between the material and the enamel surface (950X) showing irregularities in the interaction between primer/enamel, areas with gaps $(\mathrm{L})$ and presence of tags (T). B, C and D) Irregular primer surface after enamel dissolution. Images at $1300 \mathrm{X}, 3000 \mathrm{X}$ and $6000 \mathrm{X}$
Figure 7 - Electron micrographs: Adhesive interface and interlocking achieved by the Transbond XT bonding material in moist conditions. T-Tags, Sc-Bonding system, L-Gaps, E-Enamel, Ad-Primer. Images at 1400X, 1300X, 3000X and $6000 \times$ magnification 

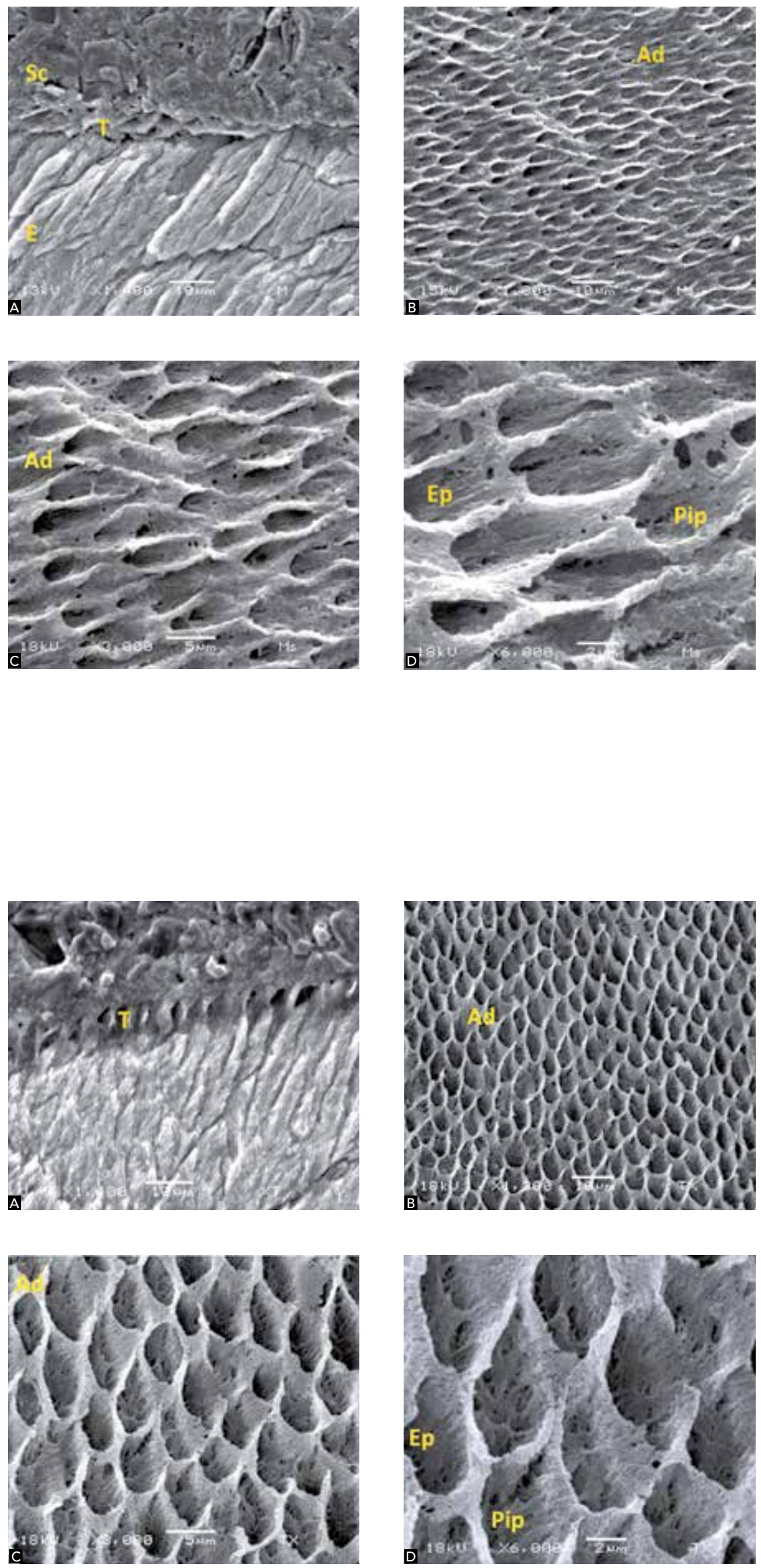

Figure 8 - Electron micrographs: Bonding interface and interlocking achieved with Transbond MIP in the absence of moisture. T-Tags, Sc-Bonding system, E-Enamel, Ad-Primer, EpSpace occupied by the rods, Pip-Inter-crystallite penetration. Images at 1400X,1300X 3000X and 6000X magnification.
Figure 9 - Electron micrographs: Bonding interface and interlocking achieved with Transbond $\mathrm{XT}$ bonding material in the absence of moisture. T-Tags, Sc-Bonding system, E-Enamel, Ad-Primer, Ep-Space occupied by the rods, Pip-Inter-crystallite penetration. Images at 1400X, 1300X, 3000X and 6000X magnification. 
interlocking was consistent in the interprismatic spaces without the presence of gaps, which had been previously occupied by water. This fact indicates that the primer (Ad) penetrated into all previously etched areas.

Figures 8C, 8D, 9C and 9D show excellent penetration of both primers. Likewise, the spaces occupied by the rods $(\mathrm{Ep})$ are clear, with the primer also penetrating the inter-crystallite spaces (Pip), thus, highlighting excellent bond strength.

\section{DISCUSSION}

Hydrophilic adhesive systems are used in restorative dentistry to ensure interaction with the dentin tissue, which is inherently moist. In this structure, etching - in association with these systems - forms a hybrid adhesive layer and dentin tags, i.e., structures that play an essential role in successful direct and indirect restorations.

During bracket bonding processes, enamel surface contamination, by blood, saliva or oral cavity moisture, is a major concern. Therefore, moisture insensitive primers are also suitable for bonding orthodontic attachments.

This research analyzed the adhesive interface of hydrophilic and hydrophobic bonding materials under different substrate conditions using scanning electron microscopy (SEM). This method provides good image resolution, allowing detailed observation of the substrate and the interfaces produced by adhesive systems. . $^{2,4,5,8,16,18,19,23,25,28}$

The results demonstrate that the specimens in Group I developed adequate micromechanical interlocking between adhesive system and enamel, forming resin tags in the interprismatic spaces, although cracks and/or gaps were also observed in some regions. This performance, even in the presence of moisture, is possibly related to the composition of the primer.

The outcome of this study may explain the findings of Cacciafesta et $\mathrm{al},{ }^{18}$ who achieved the highest bond strength in contaminated enamel using hydrophilic systems. This study emphasizes the limitations of using hydrophobic systems in contamination cases in which the substrate had been previously etched.

No adhesion relation was observed in specimens of Group 1l, which showed low interaction between enamel and primer, allowing the formation of gaps in the adhesive/enamel interface and a lack of tags which, even when present, were restricted to small areas. These observations are also justified by the composition of the primer, which contains no carrier or hydrophilic resin monomers. Thus, once the etched area is moist, a reliable bonding interface is unlikely to develop if moisture control is not absolute. Webster et $\mathrm{al}^{30}$ compared the effectiveness of these materials in moist conditions, and concluded that when hydrophobic primers are used in moist conditions they provide low bond strength.

The results yielded in Groups III and IV showed that, in the absence of moisture, all bonding systems used in this investigation displayed micromechanical interaction with the enamel structure and the development of numerous, continuous, gap-free tags. Undoubtedly, successful bonding could only be achieved through the demineralizing action of phosphoric acid, which removed the aprismatic layer and exposed the spaces between the enamel rods. When these spaces were present on a surface with high surface energy and no contamination, they were easily filled by the primers, which also exhibited low viscosity. The findings of this study corroborate those of Cal-Neto et $\mathrm{al},{ }^{19}$ who used SEM to assess the behavior of conventional hydrophobic primers in dry conditions, noting that there was adequate bonding between adhesive and enamel with the development of long, uniform tags and adequate micromechanical interlocking.

Data from this study associated with those obtained from the literature allow the authors to assert that the best condition for the application of primers to dental enamel occurs in the absence of moisture, regardless of bonding system features. However, the use of moisture insensitive (hydrophilic) systems is recommended, given the clinical impossibility of ensuring that the application areas are 100\% dry.

\section{CONCLUSIONS}

This study led the authors to conclude that: (a) the absence of moisture in etched enamel enabled better interaction between bonding materials and the adamantine structure; (b) the hydrophobic primer achieved the worst micromechanical interlocking results when applied to a moist dental structure; and (c) the hydrophilic system proved versatile, accomplishing acceptable results in moist conditions and excellent interaction in the absence of contamination. 


\section{REFERENCES}

1. Aljubouri YD, Millett DT, Gilmour WH. Laboratory evaluation of a selfetching primer for orthodontic bonding. Eur J Orthod. 2003:25(4):411-5.

2. Antonucci JM, MacKinney JE, Stansbury JW. Resin-modified glass ionomer cement. US patent application. 1988;856:7-160.

3. Arnold RW, Combe EC, Warford JH Jr. Bonding of stainless steel brackets to enamel with a new self-etching primer. Am J Orthod Dentofacial Orthop. 2002;122(3):274-6

4. Ajlouni R, Bishara SE, Oonsombat C, Denehy GE. Evaluation of modifying the bonding protocol of a new Acid-Etch primer on the shear bond strength of orthodontic brackets. Angle Orthod. 2004;74(3):410-3.

5. Buonocore MG. A simple method of increasing the adhesion of acrylic filling materials to enamel surfaces. J Dent Res. 1955;34(6):849-53.

6. Buyukyilmaz T, Usumez S, Karaman Al. Effect of self-etching primers on bond strength - are they reliable? Angle Orthod. 2003;73(1):64-70.

7. Bishara SE, Vonwald L, Laffoon JF, Jakobsen JR. Effect of altering the type of enamel conditioner on the shear bond strength of a resinreinforced glass ionomer adhesive. Am J Orthod Dentofacial Orthop. 2000;118(3):288-94.

8. Bishara SE, VonWald L, Laffoon JF, Warren JJ. Effect of a self-etch primer/adhesive on the shear bond strength of orthodontic brackets. Am J Orthod Dentofacial Orthop. 2001;119(6):621-4.

9. Bishara SE, VonWald L, Laffoon JF, Warren JJ. Effect of using a new cyanoacrylate adhesive on the shear bond strength of orthodontic brackets. Angle Orthod. 2001;71(6):466-9

10. Bishara SE, Ajlouni R, Laffoon J, Warren J. Effects of modifying the adhesive composition on the bond strength of orthodontic brackets. Angle Orthod. 2002;72(5):464-7.

11. Bishara SE, Ajlouni R, Laffoon JF, Warren JJ. Effect of a fluoride-releasing self-etch acidic primer on the shear bond strength of orthodontic brackets. Angle Orthod. 2002;72(3):199-202.

12. Bishara SE, Laffoon JF, VonWald L, Warren J. Effect of time on the shear bond strength of cyanoacrylate and composite orthodontic adhesives. Am J Orthod Dentofacial Orthop. 2002:121(3):297-300.

13. Bishara SE, Ajlouni R, Laffoon JF. Effect of thermocycling on the shear bond strength of a cyanoacrylate orthodontic adhesive. Am J Orthod Dentofacial Orthop. 2003:123(1):21-4

14. Bertoz FA, Komatsu J, Okida RC, Mendonça MR. Ionômero de vidro como meio cimentante de bráquetes. Estudo clínico. Ortodontia. 1991;24(1):41-3

15. Briso ALF, Pimenta LAF. Uso dos híbridos de ionômero de vidro e resina composta na clínica odontológica. Rev Bras Odontol. 2001:58(1):40-3.

16. Brown CR, Way DC. Enamel loss during orthodontic bonding and subsequent loss during removal of filled and unfilled adhesives. Am J Orthod. 1978;74(6):663-71.
17. Bhad WA, Hazarey PV. Scanning electron microscopic study and shear bond strength measurement with $5 \%$ and $37 \%$ phosphoric acid. Am J Orthod Dentofacial Orthop. 1995;108(4):410-4.

18. Cacciafesta V, Sfondrini MF, De Angelis M, Scribante A, Klersy C. Effect of water and saliva contamination on shear bond strength of brackets bonded with conventional, hydrophilic, and self-etching primers. Am J Orthod Dentofacial Orthop. 2003;123(6):633-40

19. Cal-Neto JP, Miguel JA. Scanning electron microscopy evaluation of the bonding mechanism of a self-etching primer on enamel. Angle Orthod. 2006;76(1):132-6.

20. Chamda RA, Stein E. Time-related bond strengths of light-cured and chemically cured bonding systems: an in vitro study. Am J Orthod Dentofacial Orthop. 1996;110(4):378-82.

21. Ching E, Cook PA, Bubb NL, Wood DJ. The effect of early static loading on the in vitro shear/peel bond strength of a "no-mix" orthodontic adhesive. Eur J Orthod. 2000;22(5):555-9.

22. Correr Sobrinho L, Correr GM, Consani S, Sinhoretti MAC, Consani RLX. Influência do tempo pós-fixação na resistência ao cisalhamento de bráquetes colados com diferentes materiais. Pesqui Odontol Bras. 2002:16(1):43-9

23. Cucu M, Driessen $\mathrm{CH}$, Ferreira PD. The influence of orthodontic bracket base diameter and mesh size on bond strength. SADJ. 2002:57(1):16-20.

24. Dorminey JC, Dunn WJ, Taloumis LJ. Shear bond strength of orthodontic brackets bonded with a modified 1-step etchant-and-primer technique. Am J Orthod Dentofacial Orthop. 2003:124(4):410-3.

25. Fox NA, McCabe JF, Buckley JG. A critique of bond strength testing in orthodontics. Br J Orthod. 1994:21(1):33-43.

26. Ferracane JL, Berge HX, Condon JR. In vitro aging of dental composites in water: effect of degree of conversion, filler volume, and filler/matrix coupling. J Biomed Mater Res. 1998;42(3):465-72.

27. Fritz UB, Diedrich $P$, Finger WJ. Self-etching primers: an alternative to the conventional acid etch technique? J Orofac Orthop. 2001;62(3):238-45.

28. Guan G, Asai Y, Matasa GC. Resistência da colagem em relação à interface esmalte-adesivo. Rev Dental Press Ortod Ortop Facial. 1998:3(3):93-9.

29. Hobson RS, McCabe JF, Hogg SD. Bond strength to surface enamel for different tooth types. Dent Mater. 2001:17(2):184-9.

30. Webster JM, Nanda SR, Duncanson GM, Sharukh S, Sinhá KP. The effect of saliva on shear bond strengths of hydrophilic bonding systems. Am J Orthod Dentofacial Orthop. 2000;119(1):54-8. 